\title{
DECONSTRUCTING SOCIAL COHESION: TOWARDS AN ANALYTICAL FRAMEWORK FOR ASSESSING SOCIAL COHESION POLICIES
}

\author{
MENNO FENGER ${ }^{l}$
}

\begin{abstract}
Academics as well as policy-makers consider social cohesion to be an important quality of cities. A high level of social cohesion is associated with a wide variety of positive characteristics of cities: for instance low crime rates, high economic growth, low unemployment and happy citizens. This has lead to a wide variety of policy initiatives explicitly or implicitly aimed at increasing social cohesion. The perceived importance of social cohesion is in remarkable contrast to the lack of its clear definition and a widely agreed-upon analytical framework. The lack of conceptual consensus may be explained by the complexity of the concept. It has multiple dimensions and can be found on different institutional levels: from the level of states to the level of local neighborhoods. In this article I develop an analytical framework that builds upon these multi-dimensional and multi-level characteristics and connect this with an attempt to classify policies aimed at increasing social cohesion.
\end{abstract}

KEYwORDs social cohesion, local policies, trust, social capital

\section{INTRODUCTION}

The summer of 2011 was one that people living in London, or those watching the events through new or traditional media, will not easily forget. The images of thousands of youths rioting and looting in the streets of Tottenham and other London neighborhoods shocked and surprised many people. Attempts to accurately explain these riots need to take into account a complex set of factors, conditions and incidents, and therefore are doomed to fail.

However, both within nation states and at the European level, many problems

1 Menno Fenger is associate professor of Public Administration at Erasmus University, Rotterdam; e-mail:fenger@fsw.eur.nl 
with modern societies are attributed to the perceived lack of 'social cohesion' among citizens, and a general mistrust of authority and public officials. Increasing the level of social cohesion is considered by many institutions to be the best way to limit the chances of incidents or riots such as those that happened. Moreover, social cohesion is thought to have many other benefits. For instance, the Council of Europe identified social cohesion as one of the primary needs of Europe, as well as an essential supplement to the promotion of human rights and dignity, and defined it as being the ability of a society to ensure the welfare of all its members, minimizing disparities and avoiding polarization (Council of Europe 2005). But, in contrast with the value that is attributed to social cohesion, the content of the concept is rather vague and disputed. The lack of a clear and concise definition has also been observed within the European Parliament. When discussing the Fourth progress report on economic and social cohesion the Parliament stated that it regretted the lack of cross-country data and comparable data from different NUTS levels which would give a better insight into the sustainability of growth and convergence (Resolution on the Fourth report on economic and social cohesion, European Parliament, 2008). The goal of this article is to build an analytical framework that takes into account the multi-dimensional character of social cohesion and that illustrates the complex causal relations between measures aimed at increasing social cohesion and their actual impacts. Such a conceptual framework can enable scholars and policy-makers to better analyze social cohesion.

\section{TOWARDS A DEFINITION OF SOCIAL COHESION?}

More than a century ago, Durkheim (1893) stated that there was neither a clear definition of the concept of social cohesion nor was it possible to directly measure it. In his view, "shared loyalties and solidarity" were the key factors in social cohesion. According to Durkheim, there were two types of solidarity: mechanical solidarity and organic solidarity. Mechanical solidarity referred to the traditional uniformity of collective values and beliefs. Organic solidarity was the result of modern relationships between individuals who are able to work together while developing an autonomous and even critical personality with respect to tradition. Over a century after Durkheim presented his inspiring thoughts on social cohesion, the concept has gained enormous popularity while none of Durkheim's initial hesitations concerning its definition and measurement have vanished. Social cohesion still is considered to be a concept that is hard to measure, difficult to achieve and to some extent 
immune to public policies (see for instance, Council of Europe 2005). There are a wide variety of definitions for the concept of social cohesion and an even wider variety of indicators that are reported to be associated with social indicators. Moreover, opinions differ about the level at which social cohesion should be analyzed: is it an attribute of individuals, local communities, cities, regions or even countries?

Despite the fuzziness that is connected with social cohesion as a concept, different actors in local communities emphasize the importance of social cohesion. For instance, Job Cohen, the former mayor of the Dutch city of Amsterdam, once defined his central mission as a mayor in multi-cultural Amsterdam as "de boel bij elkaar houden" (keeping it all together). Furthermore, many important national and international actors attribute a great deal of importance to the idea of social cohesion. For example, the World Bank states that: "Increasing evidence shows that social cohesion is critical for societies to prosper economically and for development to be sustainable" (World Bank 1999).

In the European Union, the concept of social cohesion has gained importance since the Treaty of Maastricht (1992). This Treaty contained the following objective: "promote economic and social progress which is balanced and sustainable, in particular through the creation of an area without internal frontiers, through the strengthening of economic and social cohesion and through the establishment of economic and monetary union." (Maastricht Treaty, Article 2). The Treaty of Lisbon (2007) further emphasized the importance of the social dimension of the European Union in addition to the economic dimension. Within Europe, the concept of social cohesion currently plays an important role in strengthening the social dimension of the European Union and improving the quality of life of its citizens. Therefore the lack of a clear definition and measurement of the concept within the European Union is quite remarkable. Even the subsequent Reports on Economic and Social Cohesion (see European Commission 2004, 2007) do not provide a clear and concise definition of social cohesion, although it appears to include employment rates, unemployment rates, poverty and education levels (see European Commission 2007: xii).

From the previous section we can conclude that even though the concept of social cohesion plays an important role in contemporary social policies, this concept is not clearly defined. There is no universally-recognized definition of social cohesion and conceptualizations found in the literature are at times contradictory (Rajulton et al. 2007: 461-462). What is clear is that although we are not able to define exactly what social cohesion is, it is often understood as "something that glues us together". Or, as Kearns and Forrest (2000: 996) 
state " $[t]$ he kernel of the concept is that a cohesive society 'hangs together'; all the component parts somehow fit in and contribute to society's collective well-being; and conflict between social goals and groups, and disruptive behaviors, are largely absent or minimal."

\section{FOUR DIMENSIONS OF SOCIAL COHESION}

What also becomes clear from a review of the literature is that social cohesion is a multidimensional and multilevel concept (see Friedkin 2004). In developing a definition of social cohesion we need to take into account the multidimensional and multilevel character of social cohesion. In this section I deal with the multidimensional nature of social cohesion. The following section deals with multilevel aspects. The dimensions that will be discussed are based on a review of existing literature about social cohesion, including an extensive analysis of the most-cited articles on social cohesion according to the Social Science Citation Index.

Recently, several attempts have been undertaken to integrate several approaches to social cohesion into one definition with multiple indicators (see for instance, Council of Europe 2005; Rajulton et al. 2006; Jenson 1998; Woolley 1998; Bernard 1999; Berger-Schmidt 2000; Kearns et al. 2000; Kronauer 2002; Chiesi 2004; Maloutas et al. 2004). A commonly used multi-dimensional interpretation of social cohesion has been developed by Jenson (1998). She distinguishes between five dimensions of social cohesion: inclusion, recognition, belonging, legitimacy and participation. By adding equality, Bernard (1999) expanded this list to six.

Another much-cited multi-dimensional approach has been developed by Berger-Schmitt and Noll (2000). They state that "The concept of social cohesion incorporates mainly two goal dimensions of societal development which may be related to each other but should be distinguished though analytically: The first dimension concerns the reduction of disparities, inequalities, fragmentation and cleavages which gave also been denoted as fault lines of societies. The concept of social exclusion is covered by this notion too. The second dimension embraces all forces strengthening social connections, ties and commitments to and within a community. This dimension includes the concept of social capital" (Noll, 2000: 55).

A final attempt to develop a multidimensional approach to social cohesion that is presented here is the Council of Europe's approach (see Council of Europe 2005). They make divisions between social cohesion based on shared loyalties and solidarity, social cohesion based on the strength of social relations 
and shared values, social cohesion based on trust among members, social cohesion based upon feelings of a common identity and sense of belonging to the same community and social cohesion based on the reduction of disparities, inequalities and social exclusion.

From this review, it appears that social cohesion is a multi-dimensional concept, which on the one hand is connected to the relationship between a citizen and society and on the other hand to relations between citizens themselves. More specifically, in my view, four different clusters of dimensions may be distinguished: economic, cultural, social and political. Table 1 shows how these dimensions relate to some other often-cited multidimensional approaches to social cohesion. In the remainder of this section, I will discuss these dimensions in more detail.

Table 1 Four dimensions of social cohesion

\begin{tabular}{|c|c|c|c|}
\hline Economic dimension & Cultural dimension & Social dimension & Political dimension \\
\hline $\begin{array}{l}\text { Social solidarity and } \\
\text { reductions in wealth } \\
\text { disparities (Kearns } \\
\text { and Forrest, 2000) }\end{array}$ & $\begin{array}{c}\text { Common values } \\
\text { and a civic culture } \\
\text { (Kearns and Forrest, } \\
\text { 2000) }\end{array}$ & $\begin{array}{c}\text { Social order and } \\
\text { social control } \\
\text { (Kearns and Forrest, } \\
\text { 2000) }\end{array}$ & $\begin{array}{l}\text { Participation } \\
\text { (Jenson, 1998) }\end{array}$ \\
\hline $\begin{array}{l}\text { Inclusion (Jenson, } \\
\text { 1998) }\end{array}$ & $\begin{array}{l}\quad \text { Place attachment } \\
\text { and identity (Kearns } \\
\text { and Forrest, 2000) }\end{array}$ & $\begin{array}{l}\text { Social networks } \\
\text { and social capital } \\
\text { (Kearns and Forrest, } \\
\text { 2000) }\end{array}$ & $\begin{array}{c}\text { Legitimacy } \\
\text { (Jenson, 1998) }\end{array}$ \\
\hline $\begin{array}{l}\text { Differences and } \\
\text { divisions (O’Connor, } \\
\text { 1998) }\end{array}$ & $\begin{array}{c}\text { Belonging } \\
\text { (Jenson, 1998) }\end{array}$ & $\begin{array}{r}\text { Recognition } \\
\text { (Jenson, 1998) }\end{array}$ & \\
\hline $\begin{array}{c}\text { Absence of social } \\
\text { exclusion (Woolley, } \\
1998 \text { ) }\end{array}$ & $\begin{array}{l}\text { Ties that bind } \\
\text { (O'Connor, 1998) }\end{array}$ & $\begin{array}{c}\text { Social glue } \\
\text { (O’Connor, 1998) }\end{array}$ & \\
\hline \multirow[t]{2}{*}{$\begin{array}{c}\text { Equality (Bernard, } \\
1998)\end{array}$} & $\begin{array}{l}\text { Shared values } \\
\text { and communities } \\
\text { of interpretation } \\
\text { (Woolley, 1998) }\end{array}$ & $\begin{array}{l}\text { Interactions and } \\
\text { connections based } \\
\text { on social capital } \\
\text { (Woolley, 1998) }\end{array}$ & \\
\hline & $\begin{array}{c}\text { Shared loyalties and } \\
\text { solidarity (Council } \\
\text { of Europe, 2005) }\end{array}$ & & \\
\hline
\end{tabular}

\section{The economic dimension of social cohesion}

One of the most prominent examples of the economic dimension of social 
cohesion may be found in the European Union. For instance, the Third Report on Economic and Social Cohesion (European Commission 2004: 20) states that "Maintaining social cohesion is important not only in itself but for underpinning economic development which is liable to be threatened by discontent and political unrest if disparities within society are too wide. Access to employment is of key significance since it determines in most cases whether people are able to both enjoy a decent standard of living and contribute fully to the society in which they live. For those of workingage, having a job or being able to find one within a reasonable period of time is, therefore, invariably a precondition for social inclusion." In this interpretation, disparities in wealth and employment are narrowly connected to the idea of social cohesion: in cohesive societies, disparities are rather low. The rationale behind attempts to increase social cohesion is also primarily economic: in cohesive societies, productivity and growth in GDP allegedly benefit from strong social cohesion. Most of the available evidence for this hypothesis is based on social cohesion as ethnic homogeneity, which is too limited for the multi-dimensional view of social cohesion that this article makes a plea for. But we will use some of it to demonstrate the potential effect of social cohesion from an economic dimension. For instance, in a cross section of (mainly African) countries, Easterly et al. (1997) find that ethnic heterogeneity promotes corruption and rent-seeking behavior and leads to inefficient policies which result in poor infrastructure and low educational achievements. They estimate that a one-standard-deviation decrease in ethnic heterogeneity increases productivity per worker by half a standard deviation and growth by a third of a standard deviation. In the United States, Glaeser et al. (1995) find that racial heterogeneity negatively affects economic growth in cities. DiPasquale et al. (1996) show that ethnic diversity is a significant determinant of ethnic unrest. In addition, and further illustrating the conceptual 'fog' that surrounds social cohesion, causality might also be argued to work the other way: economically successful societies may be more cohesive (see for instance Bates 1996).

\section{The cultural dimension of social cohesion}

The cultural dimension of social cohesion refers to interpretations that focus on the shared values of members of a collectivity and a sense of belonging of members to that collectivity. Moody and White (2003) refer to this as the 'ideational component' of social cohesion. A characteristic definition of this interpretation has been developed by the Social Cohesion Network (quoted 
by Stanley 2001; see Council of Europe 2004, p. 25). This network defines social cohesion as "the ongoing process of developing a community of shared values, shared challenges and equal opportunities based on a sense of hope, trust and reciprocity." Ritzen et al. (2000) define a social cohesive society as " $(\ldots)$ a society which offers opportunities for all its members within a framework of accepted values and institutions." This interpretation to some extent resembles Durkheim's concept of mechanical solidarity.

\section{The social dimension of social cohesion}

The social dimension of social cohesion has two features. On the one hand, it refers to the inclusion of members in a community. This feature is closely related to the notion of 'social capital' as popularized by Putnam (1993, 1995, 2000). Here, social capital is associated with the networks of relationships that people build to resolve common problems, obtain collective benefits or exercise a certain amount of control over the environment. Participation in all kinds of networks, including neighborhood networks, co-operatives and clubs, has a positive effect on the level of mutual trust in a community. Many collective action problems can be overcome through co-operation, and voluntary co-operation is easier and more likely to be spontaneous where social capital exists (Forrest et al. 2001). On the other hand, it refers to the ability of community members to cooperate in order to reach collective goals. This element resembles Durkheim's idea of organic solidarity. A good example of a definition that is based upon this interpretation of social cohesion has been formulated by Reimer (2002). He states that "social cohesion is the extent to which people respond collectively to achieve their valued outcomes and to deal with the economic, social, political or environmental stresses (positive or negative) that affect them." As both elements require the actual interactions of community members, we may classify them both under the social dimension.

\section{The political dimension of social cohesion}

The political dimension of social cohesion is related to the performance of communities as political systems. In socially cohesive communities, citizens feel involved in the political process. Several scholars have used aspects of involvement and participation as social indicators. Such aspects can include voting, membership of political parties, active participation in 
interactive decision-making processes and political activity. Engagement between citizens and (local) political institutions contributes to the legitimacy of government. This legitimacy also strongly depends on the performance of, and faith in, the government. Putnam (2002) suggests that the current decline in faith in these institutions represents a reduction in the ability of the political system to achieve shared goals. The existence of social capital depends on trust and cooperation that make collective action possible and effective (Hague et al 2007; Kearns et al. 2000). This has two implications. First, consensus improves social cohesion. For example, redistribution policies stimulates social consensus which enables collective (economic) activities (Bellettini et al. 1999). Social cohesion can be seen as a key resource for societies as it seems to oil the wheels of both democratic politics as well as economic prosperity (Rothstein et al. 2002). On the other hand, the active involvement of citizens in the development, governance and management of local (welfare) services might contribute to social cohesion. When citizens are involved in local policy decisions and implementation, this might contribute to the legitimacy and quality of the decision-making and implementation processes. But this involvement can also create a sense of 'belonging' and 'community' that goes beyond the specific domain in which the policy is targeted. In these cases, user-engagement and participation might contribute to social cohesion as well.

\section{LOCALIZING SOCIAL COHESION}

Social cohesion is not confined to being a multidimensional concept, it is also applicable to diverse contexts and levels of analysis. It might be considered at the micro-level to be an attribute of individuals, at the macro level to be an attribute of countries or even federal systems like the European Union, and everything in between (see Friedkin 2004). The spatial scale on which analyses of social cohesion take place vary anywhere from transnational systems like the European Union to the entities of small neighborhoods (see Turok 2006). The country level seems to be the most-frequently used level because it enables cross-national comparisons. But focusing on the country-level ignores the wide variation in social cohesion within countries. For instance, DaytonJohnson (2001) illustrates the variety in the levels of trust in a Canadian region. A similar analysis can be performed for European countries. Table 2 illustrates the variety of levels of trust within several European countries for which data are available from the 2005 World Values Survey by showing the region with the highest and the lowest rate. The question that is asked in the 
survey is: "Generally speaking, would you say that most people can be trusted or that you need to be very careful in dealing with people?" Although trust is only one possible indicator of social cohesion, the table is illustrative of the need to go beyond the country level when assessing social cohesion.

Table 2 Within-country variety in trust

\begin{tabular}{|c|c|c|c|c|}
\hline Country & Highest region & $\begin{array}{c}\text { Most people can } \\
\text { be trusted }\end{array}$ & Lowest region & $\begin{array}{c}\text { Most people can } \\
\text { be trusted }\end{array}$ \\
\hline Finland & $\begin{array}{c}\text { Varsinais- } \\
\text { Suomi }\end{array}$ & $66.3 \%$ & Kanta-Häme & $27.3 \%$ \\
\hline France & South-East & $29.8 \%$ & North & $7.9 \%$ \\
\hline Germany & Bremen & $72.0 \%$ & Thueringen & $19.0 \%$ \\
\hline The Netherlands & Drenthe & $59.2 \%$ & Zeeland & $34.3 \%$ \\
\hline Norway & $\begin{array}{c}\text { Western } \\
\text { Norway }\end{array}$ & $77.8 \%$ & $\begin{array}{c}\text { Agder and } \\
\text { Rogaland }\end{array}$ & $62.1 \%$ \\
\hline Romania & $\begin{array}{c}\text { South } \\
\text { Development } \\
\text { Region }\end{array}$ & $28.2 \%$ & $\begin{array}{c}\text { West } \\
\text { Development } \\
\text { Region }\end{array}$ & $7.4 \%$ \\
\hline Spain & Canaries & $37.5 \%$ & Galicia & $3.8 \%$ \\
\hline Great-Brittan & Eastern & $37.5 \%$ & North West & $23.2 \%$ \\
\hline
\end{tabular}

Although arguments can be put forward for analyzing social cohesion at almost any level, the analytical framework that is built up in this article focuses on the city level. There are three reasons why in my view the city level is the most appropriate for analyzing social cohesion. First, individuals observe and shape social cohesion through interactions with other people. The overwhelming majorities of European citizens live, recreate, consume, interact and participate in social networks in their cities. Therefore, social cohesion is experienced by these citizens in their daily interactions with other citizens in cities. The city level is the level that is closest to the local communities for which reliable and comparable data are available (see Forrest \& Kearns 2001).

Second, particularly in economic-geographical analyses and urban economics, the impact of social, cultural and economic characteristics of cities on their economic performance is demonstrated. The works of Edward Glaeser (Berry et al. 2005; Glaeser 1999) and Richard Florida (2002) have shifted the attention of policy-makers throughout the world to the city level. This has initiated a lot of policy initiatives that have been targeted at the level 
of cities. The insights from this particular stream of literature are considered to be a strong argument for focusing on the city level. Moreover, as Ache et al. (2008) argue, cities have become key territory for the current mode of capitalism: They organize the immobile infrastructure such as communication as well as the systems of social reproduction as frameworks for capitalist production (see also Brenner 1999).

The third reason is that obvious social cohesion deficits, particularly riots, often manifest themselves at city levels. For instance, large-scale unrest between young Greeks and the police occurred in Athens in 2009 but not in other Greek cities. Riots between North-African migrants and the police, including the torching of cars on a massive scale, occurred almost exclusively in Paris in 2005 and not in other French cities. The London riots, with which I opened this article, started in London and remained concentrated in that city for a couple of days, although some rioting in other British cities occurred as well. These incidents illustrate the local dimension of social challenges and emphasize the necessity of focusing on the city level (see DiPasquale et al 1996).

\section{THE COMPLEX CAUSALITY OF IMPROVING SOCIAL COHESION}

Local governments explicitly and implicitly have a wide variety of policies that may directly or indirectly affect social cohesion. Most notably, all kinds of social policies are sometimes assumed to impact social cohesion, including the facilitation of participation in employment and access by all to resources, rights, goods and services, the prevention of the risk of exclusion and assistance to the most vulnerable in societies. The wide variety of policy initiatives both between and within local communities complicates a thorough assessment of the impact of local welfare systems on social cohesion. The multidimensionality of the social cohesion concept suggests that (combinations of) policy interventions on any of these dimensions might have impacts on the level of social cohesion in European cities. The range of possible interventions modes of governance and public sector management is seemingly endless. It includes the organization of neighborhood-barbecues, redistributing income, facilitating membership of sport clubs for the lowest income groups, etc. In general, policy-makers as well as researchers tend to treat these policy interventions as uncomparable and separate entities. But if we accept the importance of social cohesion at the city-level and we embrace a multidimensional definition of social cohesion, a comprehensive approach is required to assess the impacts of each of these interventions. 
Lasswell's famous description of politics - who gets what, when and how - takes as a starting-point Gilbert et al's influential typology of social policies. Gilbert et al. (1986: 37) build upon Burns' seminal study 'Social Security and Public Policy' (1956). She focused on four types of decisions about social security programs: "(1) Those related to the nature and amount of benefits; (2) those concerned with eligibility and the type of risks to be covered; (3) those regarding the means of financing social security; and (4) those relevant to the structure and character of administration." These dimensions of social policy depart from the questions about what benefits are to be offered in a local welfare system, to whom they are offered, how these benefits are to be delivered, and how they are to be financed. The typology of local welfare systems that will be used in this article will also be based on these issues. In the analytical framework that is proposed, I propose to take into account 7 dimensions of local welfare systems. The first dimension concerns the actors at which the local welfare policies are targeted. Secondly, the types of resources that the policies involve may be of importance for characterizing local welfare systems. Third, the type of service providers and their institutional backgrounds need to be taken into account. Fourth, building upon the insights from this article, the dimension of social cohesion at which the policy is aimed is important. In the fifth place, the way in which the local welfare policy is financed is an important element. A sixth element concerns the type of governance that regulates the relation between the service provider and the responsible government. Finally, the way the target groups of the policies are involved in the development and implementation of the policies is an important element of the analytical framework.

In table 3 this preliminary typology is used to illustrate both the value of this typology and the variety of local welfare policies that directly or indirectly affects social cohesion. Ten examples have been included in the following table, although the list of possible local policies is nearly endless. This table clearly illustrates the variety of local policies that affect social cohesion in European cities.

Two striking observations may be derived from this preliminary overview. First, the variety of policies that directly or indirectly may affect social cohesion is enormous. This list is based on a first explorative analysis of striking examples, and could be extended without much effort. The variety therefore requires systematic classification in order to build up a body of knowledge usable for scholars and practitioners. This brings us to the second observation: the available evidence about the actual impact of these interventions is limited; on the verge of being absent. Moreover, even when these policies are explicitly aimed at social cohesion, it is unsurprisingly 
Table 3. Examples of local welfare policies

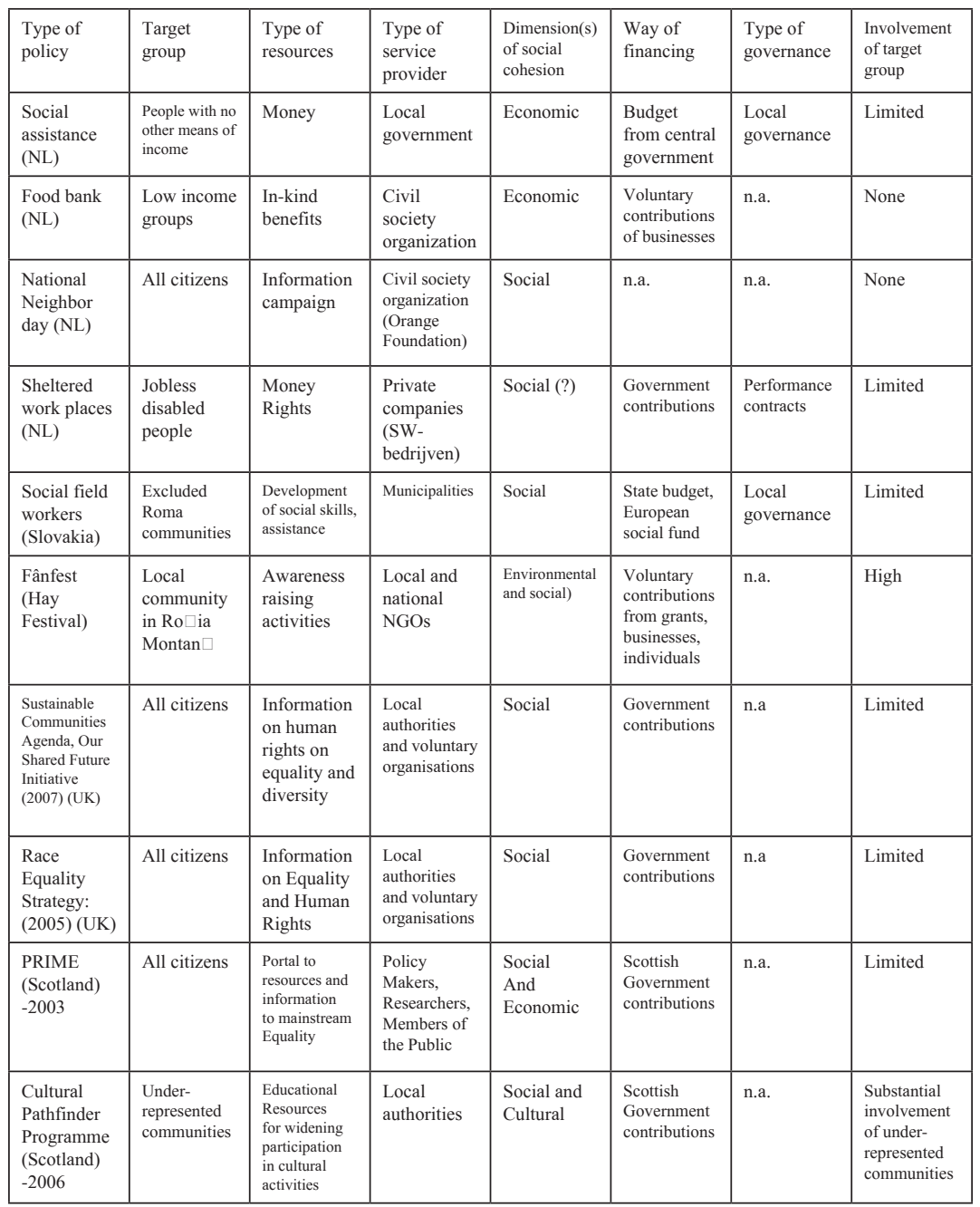


unclear what social cohesion is or how it should be measured, even according to those that initially designed the policies. These observations make clear why it is important to create a coherent and accepted analytical framework that serves as a comprehensive guide to analyzing social cohesion in local communities and as a tool for assessing and explaining the impact of policies aimed at increasing social cohesion in local communities. This article is intended to provide some important building blocks for such an analytical framework.

\section{CONNECTING LOCAL POLICIES AND SOCIAL COHESION}

Conceptualizing social cohesion in itself is not very helpful if we wish to explain or even prevent the tensions, discontent and mistrust that are held responsible for the recent riots in European cities and many other - much less visible - problems of European cities. A systematic perspective of what social cohesion is and how it may be analyzed is a first step, but it needs to be related to indicators which assess the quality of city life and the prevalence of incidents that are usually negatively associated with socially healthy cities and communities. We may think of crime rates, poverty, physical health indicators and the like. Figure 1 proposes an analytical framework that connects local policies and social cohesion and takes into account the impact of social cohesion on European cities.

This analytical framework clearly illustrates the causal complexity of explaining the impact of local policies on social cohesion. It has been designed as an analytical tool for scholars and other stakeholders to assist in the design, analysis and evaluation of policies aimed at increasing social cohesion in European cities. It emphasizes and embraces the multi-dimensional character of the concept and thus enables a more adequate analysis of social cohesion in European cities.

Getting insight in the complex causes and consequences of social cohesion is not only an academic exercise. This article has illustrated the intensity of the efforts of policy-makers to increase social cohesion within European cities. But the absence of a shared and systematic interpretation of the concept limits the development of evidence about what social cohesion is, how it might be influenced and what its impact on the quality of life in European cities is. The analytical framework presented in this article should not be considered to be a panacea for solving all the shortcomings of European cities. But it may be considered a first step in the creation of an evidence-based body of knowledge that might help to prevent explosive situations like those of London in the 
summer of 2011 occurring.

Figure 1: Analytical framework for studying social cohesion policies

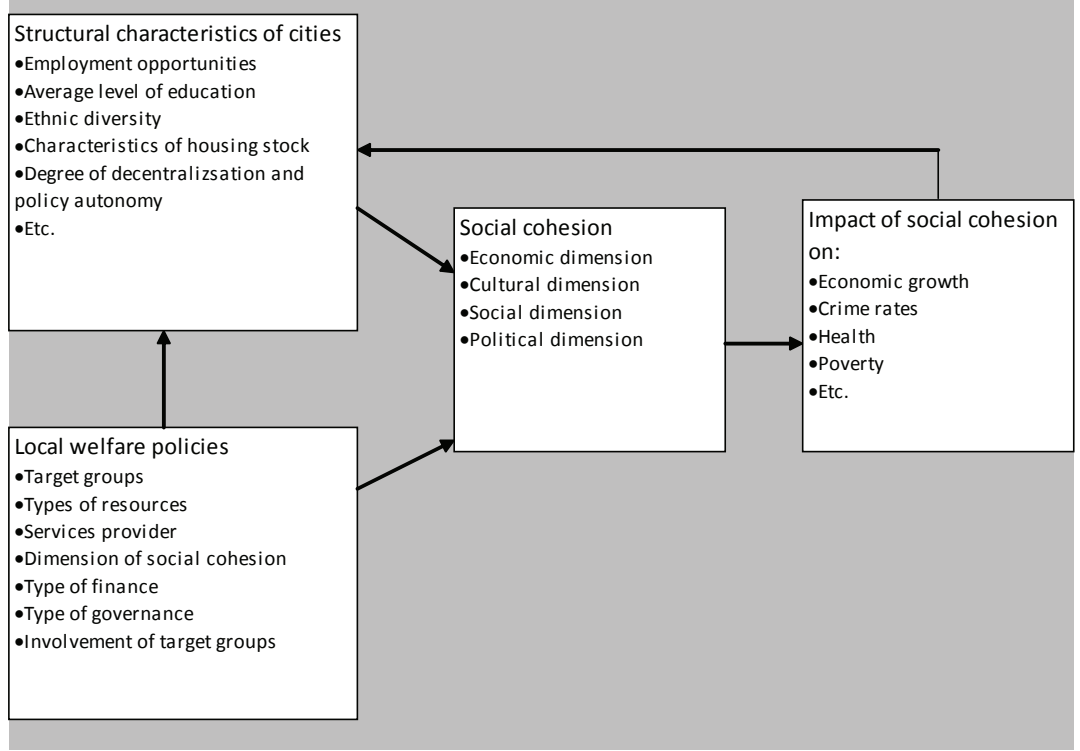

\section{REFERENCES}

Ache, Peter-Hans Thor Andersen, 2008, "Cities between Competitiveness and Cohesion: Discourses, Realities and Implementation - Introduction", in Ache, Peter, et al., eds., Cities between Competitiveness and Cohesion: Discourses, Realities and Implementation, Dordrecht, Springer, pp. 3-18.

Bates, Winton, 1996, The Links Between Economic Growth and Social Cohesion. New Zealand Business Roundtable, http:/www.nzbr.org.nz/site/nzbr/files/publications/ word-publications/social-cohesion.doc.htm, latest access 13 January 2012.

Bellettini, Giorgio-Carlotta Berti Ceroni, 1999, "Is Social Security Really Bad for Growth?” Review of Economic Dynamics, Vol. 2, No. 4, pp. 796-819.

Berger-Schmitt, Regina-Heinz-Herbert Noll, 2000, Conceptual Framework and structures Conceptual Framework and Structure of a European System of Social Indicators. EU Reporting Working Paper no. 14. Mannheim: Centre for Survey Research and Methodology (ZUMA).

Bernard, Paul, 1999, "La Cohésion sociale: critique d'un quasi-concept", Lien social 
et Politiques-RIAC, Vol. 41, 47-59.

Berry, Christopher-Edward Glaeser, 2005, “The Divergence of Human Capital Levels Across Cities", Papers in regional science, Vol. 84, No. 3, pp. 407-444.

Brenner, Neil, 1999, "Globalisation as reterritorialisation: The re-scaling of urban governance in the European Union”, Urban Studies, vol. 36, no. 3, pp.431-451.

Burns, Eveline, 1956, Social security and public policy, New York, McGraw-Hill.

Chiesi, Antonio, 2004, "Social Cohesion and Related Concepts", in Genov, Nicolai, ed., Advances in Sociological Knowledge. Over half a Century, Wiesbaden: Verlag für Sozialwissenschaften, pp. 235-254.

Council of Europe, 2005, Concerted development of social cohesion indicators. Strasbourg: Council of Europe Publishing.

Dayton-Johnson, Jeff, 2001, Social Cohesion \& Economic Prosperity. Toronto: James Lorimer \& Company.

DiPasquale, Denise-Edward Glaeser, 1996, The L.A. Riot and the Economics of Urban Unrest. (Working Paper No. 5456.) Cambridge, MA: National Bureau of Economic Research.

Durkheim, Emile, 1893, The Division of Labor in Society (Edition 1997: New York, Free Press).

Easterly, William-Ross Levine, 1997, “Africa's Growth Tragedy: Policies and Ethnic Diversions", Quarterly Journal of Economics, Vol. 112, No. 4, pp. 1203-1250.

European Commission, 2004, A New Partnership for Cohesion. Convergence, Competitiveness, cooperation. Third report on economic and social cohesion. Brussels: European Commission.

European Commission, 2007, Fourth Report on Economic and Social Cohesion, Brussels, European Commission.

Florida, Richard, 2002, The Rise of the Creative Class: And How it's transforming work, leisure, community and everyday life, New York: Perseus Book Group.

Forrest, Ray - Ade Kearns, 2001, "Social Cohesion, Social Capital and the Neighbourhood”, Urban Studies, Vol. 38, No. 12, pp. 2125-2143.

Friedkin, Noah, 2004, "Social Cohesion", Annual Review of Sociology, vol. 30, pp. 409-425.

Gilbert, Neil - Harry Specht, 1986, Dimensions of Social Welfare Policy. Englewood Cliffs: Prentice Hall.

Glaeser, Edward, 1999, "Learning in Cities", Journal of Urban Economics, Vol. 46, pp. 254-277.

Hague, Rod-Martin Harrop, 2007, Comparative government and politics: an introduction. Basingstoke: Palgrave Macmillan.

Jenson, Jane, 1998, Mapping Social Cohesion: The State of Canadian Research. Ottawa: Canadian Policy Research Networks.

Kearns, Ade \& Ray Forrest, 2000, "Social Cohesion and Multilevel Urban Governance", Urban Studies, Vol. 37, No. 5-6, pp. 995-1017.

Kronauer, Martin, 2002, Exklusion: Die Gefährdung des Sozialen im hoch entwickelten Kapitalismus. Frankfurt: Campus.

Maloutas, Thomas-Maro Pantelidou-Malouta, 2004, "The glass menagerie of 
urban governance and social cohesion: concepts and stakes/concepts as stakes", International Journal of Urban and Regional Research, vol. 28, no. 2, pp. 449-465.

Moody, James-Douglas White, 2003, "Social cohesion and embeddedness: A hierarchical conception of social groups", American Journal of Sociology, Vol. 68, pp. 103-127.

Noll, Heinz-Herbert, 2000, "Towards a European System of Social Indicators: Theoretical Framework and System Architecture", Social Indicators Research, Vvol. 30, pp. 47-87.

Putnam, Robert, 1993, Making democracy work: civic traditions in modern Italy, Princeton: Princeton University Press.

Putnam, Robert, 1995, "Bowling Alone: America's Declining Social Capital”, Journal of Democracy, Vol. 6, No. 1, 65-78.

Putnam, Robert, 2000, Bowling Alone. The collapse and revival of American community, New York: Simon and Schuster.

Putnam, Robert (ed.), 2002, Democracies in Flux: The Evolution of Social Capital in Contemporary Society. New York: Oxford University Press.

Rajulton, Fernando-Zenaida Ravanera-Roderic Beaujot, 2007, "Measuring social cohesion: An experiment using the Canadian national survey of giving, volunteering, and participating", Social Indicators Research, Vol. 80, pp. 461-492.

Reimer, Bill, 2002, Understanding Social Capital: its Nature and Manifestations in Rural Canada. Paper Prepared for Presentation at the CSAA Annual Conference Toronto, ON, http://129.3.20.41/eps/othr/papers/0511/0511002.pdf, latest access 13 January 2012

Ritzen, Jo-William Easterly-Michael Woolcock, 2000, On 'good' politicians and 'bad' policies: social cohesion, institutions and growth. World Bank Policy Research, working paper 2448.

Rothstein, Bo-Dietlind Stolle, 2002, How Political Institutions Create and Destroy Social Capital: An Institutional Theory of Generalized Trust. Paper prepared for the 98th meeting of the American Political Science Association in Boston, MA.

Turok, Ivan, 2006, "The Connections Between Social Cohesion and City Competitiveness", in OECD, ed., Competitive Cities in the Global Economy, Paris: OECD, pp.353-366.

World Bank, 1999, What is Social Capital?, http:/go.worldbank.org/K4LUMW43B0, latest access 13 January 2012. 